University of California, Hastings College of the Law UC Hastings Scholarship Repository

Faculty Scholarship

2001

\title{
Comparative Law and Economics: Borrowing and Resistance
}

Ugo Mattei

UC Hastings College of the Law, matteiu@uchastings.edu

Alberto Monti

Follow this and additional works at: http://repository.uchastings.edu/faculty_scholarship

\section{Recommended Citation}

Ugo Mattei and Alberto Monti, Comparative Law and Economics: Borrowing and Resistance, 1 Global Jurist Frontiers Art. 5 (2001). Available at: http://repository.uchastings.edu/faculty_scholarship/1288

This Article is brought to you for free and open access by UC Hastings Scholarship Repository. It has been accepted for inclusion in Faculty Scholarship by an authorized administrator of UC Hastings Scholarship Repository. For more information, please contact marcusc@uchastings.edu. 


\title{
Global Jurist Frontiers
}

Vol. 1, Issue $2 \quad 2001 \quad$ Article 5

\section{Comparative Law and Economics: Borrowing and Resistance}

\author{
Ugo Mattei* \\ Alberto Monti ${ }^{\dagger}$
}

${ }^{*}$ Hastings College of the Law; Univ. of Turin, Italy

${ }^{\dagger}$ University of Milano School of Law and ICER - International Centre for Economic Research

Global Jurist Frontiers is in the Global Jurist family of journals.

Copyright $\bigcirc 2001$ by the authors.

All rights reserved. No part of this publication may be reproduced, stored in a retrieval system, or transmitted, in any form or by any means, electronic, mechanical, photocopying, recording, or otherwise, without the prior written permission of the publisher, bepress. 


\title{
Comparative Law and Economics: Borrowing and Resistance
}

\begin{abstract}
Comparative law and economics is a rather new discipline located at the frontiers of contemporary legal research. This innovative scholarly paradigm - combining the analytical tools of adjoining and complementary social sciences in order to develop a critical approach to legal rules and institutions - conveys a distinctive European perspective on the theory and practice of law and economics. In the age of globalisation, the diffuse and substantial lack of comparative understanding within the legal community brings about a serious challenge to the epistemological validity of the traditional economic analysis of law. Comparative law and economics treats the legal and institutional backgrounds as dynamic variables and attempts to build models which reflect the ever changing layered complexity of the real world of the law, broadening the horizon of the underlying legal discourse and conferring a higher degree of realism to the theoretical analysis. The false opposition between a global dimension, which is the domain of the market and of efficient institutions, and a local dimension, as the location of solidarity and politics, requires a genuine cosmopolitan legal culture to be exposed and challenged. In other words, what is currently required is a global jurist capable to handle analogies and differences, to locate them at the proper level of the institutional scenario, to register the different sensitivities and stakes that are at play in the centre and in the periphery; a global jurist capable, in one sentence, to deconstruct the objectivity of market globalisation worldwide.
\end{abstract}




\title{
COMPARATIVE LAW \& ECONOMICS: BORROWING AND RESISTANCE •
}

\author{
by
}

Ugo Mattei and Alberto Monti

\section{Introduction}

Comparative law and economics is a rather new discipline located at the frontiers of contemporary legal research. This innovative scholarly paradigm - combining the analytical tools of adjoining and complementary social sciences in order to develop a critical approach to legal rules and institutions - conveys a distinctive European perspective on the theory and practice of law and economics.

In the age of globalisation, the diffuse and substantial lack of comparative understanding within the legal community brings about a serious challenge to the epistemological validity of the traditional economic analysis of law. Most of the founding contributions to the field of law and economics, in fact, tend to deal with general, abstract and sometimes misleading legal concepts - such as the naturalistic notion of "property tight" - and to presume a static institutional framework clearly modelled on the American legal process (comprising an effective court system, strong incentives to litigation, etc.). Such fundamental limitations so far have hindered the potential for a truly global application of law and economics' analytical techniques.

Comparative law and economics, by contrast, treats the legal and institutional backgrounds as dynamic variables and attempts to build models which reflect the ever changing layered complexity of the real world of the law, broadening the horizon of the underlying legal discourse and conferring a higher degree of realism to the theoretical analysis.

\section{The comparative approach to the legal phenomena}

Comparative law has a longstanding tradition as an advanced branch of legal scholarship in Europe. The comparative study of law and institutions is primarily aimed at discovering similarities and divergences among legal systems of the world. Being characterised by a

\footnotetext{
- A modified version of this paper will soon be published as a chapter of: HA'T'ZIS, ARISTIDES N. (ed.), Economic Analysis of I ay: a European Perppective, Edward Elgar Pub. (2001). The authors wish to thank the editor of the volume, Aristides Hatzis, and the publisher for their kind and valuable cooperation.
} 
strong non-positivistic approach to the legal phenomenon, the comparative methodology presupposes the existence of a plurality of legal rules and institutions and it compares them in order to establish to what extent they are identical or different.

The comparative analysis of law is founded upon the actual observation of the elements at work in a given legal system and, therefore, it brings about a better and deeper knowledge of the various systems compared. Law and legal institutions are perceived as tools to manage the social complexity. When approaching the study of a particular legal system, the comparative lawyer does not merely focus the analysis on the body of positive laws at present in force, but rather on every proposition that affects the solution of a legal problem (Sacco, 1991), aiming at the understanding of the deeper structure that characterises such system in the medium-long run. In this perspective, special attention is devoted to the structure of the legal process, the cultural values and the historical roots that may influence the local legal discourse, the balance and hegemonic relationship among the rule of law, politics and tradition (Mattei 1997a), the role of lawyers, judges and academics (Gambaro, 1983; Dawson, 1968), the formal and informal sources of the law in action (statutes, regulations, judicial decisions, scholarly writing, etc.), the comparative importance of such 'legal formants' - or actual formative parts of the legal system, in the sense made clear by: Sacco, 1991 - in order to establish which one prevails in determining the outcome of a certain legal issue (the working rule), the dichotomy between operational rules and the rhetoric used to justify them, the origins and development of technical legal concepts and the way in which lawyers think about legal issues (the so-called mentality).

According to one of the core propositions of the comparative methodology, within each legal system there co-exist several "legal formants", or formative parts of the legal discourse, which may or may not be in harmony with each other (Sacco 1991; Monateri\& Sacco 1998; Schlesinger, Baade, Herzog, Wise 1998 ). The black letter rule stated in an article of the civil code, for example, may not be in accordance with a general provision of the constitution and it may also differ substantially from the operational rule applied by the courts, which in turn may be contrasted by the interpretation of the same legal rule offered by scholars and academics. In those legal orders in which courts are required to provide an explanation for their decisions, moreover, the declamatory statements and the general doctrines announced by the judge may not be fully coherent with the working rule employed in the solution of the actual controversy (Monateri and Sacco, 1998). The law in action is also influenced by tacit elements, such as implicit propositions, or formal ways of 
reasoning that are part of the common mentalite of jurists belonging to a given legal system, even if they are not clearly translated into words (Sacco, 1991; Le Grand 1999). Each of these elements takes active part in the solution of the targeted legal issue and subsequent evolutions of the law may be affected by the co-existence of conflicting statements. Comparative lawyers aim at understanding the interaction among legal formants, trying to deconstruct the system in order to identify the role of the different forces at play.

Comparative law and economics goes further along this line, addressing the relationship between different formative elements which contribute in the making of any legal rule. The basic idea is that competition rather than hierarchy captures the actual relationship between sources of legal authority (Mattei and Pulitini, 1991).

The comparative legal discourse is both structural and functional. A substantial amount of comparative research, in fact, is devoted to the understanding of how different legal systems deal with analogous factual situations. Within the Western Legal Tradition (Gambaro, 1998), divergent legal formulation very often conceal functional similarities at an operational level. This hypothesis is at the basis of the 'common core' trend of research inaugurated a few decades ago by the pioneering study of Rudolph Schlesinger on the formation of contracts (Schlesinger, 1968) and currently carried on by several international scholars under the auspices of the Trento Project (Bussani and Mattei, 1998 and 2000).

Employing the so-called 'factual approach', comparative analysis gains the ability to bridge the taxonomic gaps created by the differences in legal concepts, abstract doctrines and formal or technical constructions of the law. In this sense, comparative law is deeply antidogmatic and anti-positivistic. The taxonomic framework varies quite drastically in the law and only by looking beyond it and performing factual problem-based analysis of the law in action does it become possible to explore the economic analysis of differences and similarities in the law (Mattei and Cafaggi, 1998; see also: Posner, 1996).

This does not mean that only working rules are relevant in the comparative and economic study of law. To the contrary, different procedural and institutional arrangements, remedial devices, legal ideologies, doctrinal constructions and cultural constraints are to be taken into account, since all these variables influence the total amount of transaction costs associated to the solution of any legal controversy.

Comparing transaction costs imposed in the real world by different legal systems might introduce some possibility of measurement and of a more rigorous comparison than otherwise possible. The value of such possibility is of extraordinary importance both in 
terms of understanding and of policy-making and may be considered a fundamental contribution of economics to comparative law. (See Ogus 1999)

Another important advancement in the filed of comparative law is constituted by the study of patterns of legal change (Watson 1974). Comparative law perceives legal rules and institutions as dynamic elements of the society and 'examines the way in which legal institutions are connected, diversified and transplanted from one country to another. Law, language and culture break down into cultural, linguistic and legal morphemes' (Sacco, 1991). In this perspective, legal systems are considered the result of a layered complexity that stems from the accidents of legal history and from legal transplants (Mattei, 1997a). Legal systems are dynamic in nature and extremely responsive to change: they never are, they always become. The comparative and historical study of legal system, however, shows that legal change is rarely a process of radical innovation, it is rather a process of interactions, borrowings and receptions (Watson, 1974). It is important to note that borrowings and receptions may affect differently the various layers of the receiving system, or they may concern only specific areas of law, thereby provoking increased complexity (Grande, 2001).

\section{Economic theory and the advancement of comparative legal research}

Having accomplished extremely important results in the understanding of the legal systems of the world, comparative law has too often lacked a theoretical structure to provide explanations and to develop a strong normative attitude.

Employing the analytical tools provided by economics, comparative law may proceed a step forward in its target of measuring and understanding analogies and differences among alternative legal patterns. Law and economics, in fact, can be used to build efficient models, which work as uniform terms of comparison for the different solutions adopted by the actual legal systems compared, in order to allow proper measurement of the distance that separates them from the theoretically efficient solution. Adopting comparative law techniques together with the economic methodology, we may be able to see if an institutional arrangement, a legal doctrine, or a legal rule of one legal system is more or less efficient than another. In a legal process style comparison of alternative legal institutions (Komesar, 1994), comparative law may offer to economic analysis a reservoir of institutional alternatives not merely theoretical but actually tested by legal history (Mattei, 1997). 
Along these lines, comparative law and economics is aimed at predicting and evaluating in economic terms the relationship between legal formants as well as between national legal orders.

Since the law can be conceived as the outcome of competition among alternative and heterogeneous suppliers of legal authority, the concept of economic efficiency may be used as an explanation for legal change. Competition is at play either among different legal orders, or between different sources of the law within a given system; within a single legal system, legal formants compete for the solution of each legal problem, while in the international arena, there exist a competition between national legal regimes (Antoniolli, 1996 Ogus 1999 ). In both these settings, the competition between suppliers of legal rules greatly affects legal change and the evolution of the law. A recent study in comparative law and economics focusing on the controversial issue of European legal integration suggests, for example, that 'competition between jurisdictions will generate a tendency for national legal principles to converge in those area of law designed primarily to facilitate trade', while in contrast 'there is, in general, no reason to expect this phenomenon to apply to interventionists areas of law because national preferences regarding the level of protection are likely to differ' (Ogus, 1999).

Taking efficiency as a working assumption, phenomena of convergence, divergence and spontaneous harmonisation may be detected and explained in more precise economic terms. The proposed approach, in fact, is suitable to explain the dynamic of legal transplants: if a transplant occurs in a competitive scenario, it is likely that the transplanted rule of doctrine is more efficient that other possible alternatives. This does not mean that there is just one efficient legal arrangement to solve a legal issue. Divergences can also be justified in terms of efficiency. Different legal traditions may develop alternative solutions for the same legal problem that are neutral from the standpoint of efficiency. In other words, the same legal rule may be efficient or inefficient depending on the institutional background it refers to and different legal rules may all turn out to be efficient when located in different institutional frameworks.

Since the law in action is understood as a synthesis both of exogenous factors, determined by culture, economic structure, and political system, and of endogenous elements, the notion of efficiency assumes itself a comparative meaning within this novel scholarly paradigm. An institution, rule or state of the world is never efficient or inefficient in an 
abstract or absolute way. It may only be so compared with actual alternatives that may fit better or worse to a given context. (Mattei 1997)

An interesting perspective on the comparative and economic analysis of legal change and legal transplants is conveyed by recent developments of neo-institutional economics. In particular, the elaboration of the concept of path dependence as a tool to explain historical evolution of institutions (North, 1990) can have fruitful application in the comparative study of legal systems.

The notion of path dependence means that once a country or region has started down a track, the costs of reversal become very high. Even if there will be other choice points, the entrenchments of certain institutional arrangements obstruct an easy reversal or modification of the initial choice. 'This conception of path dependence, in which preceding steps in a particular direction induce further movement in the same direction, is well captured by the idea of increasing returns. In an increasing returns process, the probability of further steps along the same path increases with each move down that path. This is because the relative benefits of the current activity compared with other possible options increase over time. To put it a different way, the costs of exit - of switching to some previously plausible alternative - rise. Increasing returns processes can also be described as self-reinforcing or positive feedback processes.' (Pierson, 2000; see also, for the classic discussion, Arthur, 1994).

With respect to the evolution of legal systems, innovations and changes depends heavily on the existing institutional framework as well as on the historical background. The comparative analysis of institutions shows that legal systems are frequently locked in suboptimal routines, because the transaction costs associated to change are extremely high. For example, the significant difference of legal styles and legal solutions in the company law statutes enacted by post-socialist Central and Eastern European countries, 'in spite of a common core of problems, inherited from the previous organisation of the economy (such as the monopolistic structure of the enterprises, the lack of financial markets, the weakness of domestic capital to be used as investment in the divestiture of state properties)', is an effect of path dependency (Ajani, 2001). Moreover, it has been recently suggested that legal systems, facing an emergency - such as blood contamination or environmental protection - , tend to react following pre-established, relatively predictable, paths, determined by factors deeply embedded in their respective legal cultures (Mattei, 2001; Monti 2001). 
In this perspective, the notion of comparative efficiency gains substantial importance: a certain legal arrangement may not be the most efficient one in a theoretical world, but it may well be the best achievable, in the light of the existing formal and informal constraints. The use of a path-dependence models requires a complex historical approach and, since comparative law has been traditionally concerned with the history of institutions from a legal as well as from a cultural perspective, the co-operation between comparative law and economic theory can be extremely fruitful in this field. 'The value of comparative law lies fundamentally in its capacity to explain legal developments, the relationship of law to society, and at this stage of its development, (...) the simplest way to exploit comparative law is by examining, and accounting for, similarities and differences in systems that have a historical relationship' (Watson, 2000).

Prediction of changes is crucial for appropriate global policy making. Developing a comparative and economic approach to legal change based on the study of transaction costs and path dependency, we may come closer to the ability of predicting trends and effects in the evolution of the law.

\section{Positive vs. Normative analysis: an illusory perspective.}

According to the traditional, positivistic (in the sense discussed by Katz, 1996) law and economics scholarly paradigm, discourses concerning the law can be articulated either at a positive, or at a normative level. The positive level of analysis is considered to be characterised by a substantial degree of objectiveness and neutrality, while normative discourses, proposing marginal adjustments or radical changes to the status quo, are patently aimed at influencing the evolution of the law.

The underlying tacit assumption is that law can be observed and described from a completely neutral, out-of-context, standpoint, following the epistemological model of natural sciences.

The structural approach proposed by the most advanced comparative legal scholarship, however, constitutes a challenge to the validity of this basic assumption. Lawyers, in fact, are themselves considered part of the legal system in which they operate, in whatever professional capacity they may act in it (scholars, judges, practitioners etc.). When they describe the law, their interpretation is part of the law that they are describing.

Law is not a static object, rather it is a fluid matter which is constantly changing in shape and colour. The very act of describing it contributes to the process of change. Uncovering 
hidden elements of the law in action, for example, influences the relative strength and importance of legal formants.

Law has an important practical dimension. Since the beginning of the Western legal tradition, lawyers have been arguing whether law should be more of a theoretical doctrinal enterprise or just a practical business. The commitment to doctrine and theory has been the major source of lawyers' legitimacy: they were able to claim they had a neutral approach to problem-solving (Gambaro, 1998). The practical aspect of lawyers' work, however, has made them a powerful and influential corporation of hidden law-givers (Gambaro, 1983). Due to the peculiarities of the legal phenomenon, therefore, the very idea of a purely neutral and objective analysis is illusory and misleading. Hence, among the different new approaches to comparative law (positive, normative, interdisciplinary and interpretive), CLE on top of its genuinely interdisciplinary posture has also a strongly interpretive flavour (Minda 1995 and 1999).

\section{Comparative law and economics and the Europeanisation of private law}

Private law in Europe is increasingly influenced by non-national sources of law. The law within the European Union (EU), in fact, can be understood as a polycentric multi-level system which in its vertical perspective entails all European and international norms claiming validity within the EU and in its horizontal perspective the national legal regimes of the EU member states (Bussani 2000).

At the present time, the complex and multi-faceted issue of harmonisation of private law in Europe constitutes one of the most intriguing legal challenges faced by comparative law and economics.

The constitutional structure of the Treaty clearly spells out the need to create a common and effective private law framework aimed at fostering the development of an efficient market economy based on free competition. According to its language, the creation of a common marketplace and of a monetary and economic union is a prerequisite for balanced, harmonious, sustainable growth and development, aimed at a high level of employment and of social protection, at the improvement of the standard and quality of life in the EU and at the fostering of solidarity and social and economic cohesion between the member states. In this perspective, the harmonisation of national legal systems is required to the degree necessary for the smooth operation of a common market. The fundamental principle of "subsidiarity" allows the EU to take action in areas other than 
those of its exclusive jurisdiction if the general targets set forward in Article 2 of the "Treaty on European Union' at present in force can be "better" obtained by community action rather than by State action. In other words, there is a constitutional mandate in Europe today to think about the best possible institutional arrangement for an efficient common market (Mattei, 1999; Van den Bergh, 1994).

Against this backdrop, the comparative law and economics approach can have fruitful applications at several analytical and policy levels.

First, the pragmatic view of law and economics should serve the fundamental purpose of uncovering the political implications of any choice affecting private law regimes, such as the current proposal for a European Civil Code. Under the rhetorical shadow of legal positivism, often prevailing in Europe, private law doctrines tend to maintain the appearance of political and ideological neutrality (Mattei, 1994; Caruso, 1997). To the contrary, it is extremely important to realize that the allocation of rights and remedies through private law rules entails relevant consequences in terms of both public and economic policy. Suffice it to think of the rules concerning product liability, environmental pollution, the limitation of the contractual freedom of the parties, the scope of ownership rights, the transfer of property, etc.. Focusing on the economic effects of legal rules on societal dynamics, law and economics is useful to throw some brighter light on the political implications of private law issues. As everywhere, also in the European legal battlefield there are social winners and losers.

One of the most interesting analysis of the transformation of Europe in the recent times is focused precisely on 'the interactions between norms and norm-making, constitution and institutions, principles and practice, and the Court of Justice and the political organs' (Weiler, 1991).

With a view to an efficiency oriented legal harmonisation of private law regimes, moreover, the proposed approach provides the ability to measures the comparative efficiency of different legal rules experimented in various EU member state (Kötz, 2000), taking into account the transaction costs induced by formal and informal constraints (Hansmann and Mattei, 1998).

It is interesting to note that the Commission of the European Communities, in drafting the White Paper on Environmental Liability' presented on February 9, 2000 [COM(2000) 66 final], has adopted a similar approach. Having performed a comparative survey of the different solutions tested in various national legal system with respect to civil liability for 
environmental harm, the Commission offers a prognostic assessment of the overall economic impact of environmental liability at EC level, employing a transaction costs approach to evaluate institutional alternatives. To this purpose, the Commission expressly recognises that the use of policy instruments generates costs that must be compared with the expected benefits; in order to reach an efficient solution to the targeted problem, therefore, the focus should be on minimisation of costs associated with pre-determined goals. 'In the case of liability, transaction costs, i.e. the costs of reaching and enforcing rules, is a matter of specific consideration. Three cases can be mentioned in this respect. First, the case of the US, where litigation is admittedly more widespread than in Europe, and where liability laws have entailed high transaction costs, mainly legal fees, to the tune of $20 \%$ of total enforcement and compensation costs. Secondly, for the strict environmental liability systems in the Member States, there is no evidence that they have given raise to an increase of claims or transaction costs. Finally, there is the experience in the Community with the introduction of the Product Liability Directive. A study report on the first period of application of this directive did not find any significant increase in the number or pattern of claims. It can be concluded from this that, when shaping the features of an environmental liability regime, it is important to look at the reasons for the differences in transaction costs between the different systems, and to avoid features that would in particular contribute to such costs. Rules concerning direct access to justice by parties other than public authorities should also be assessed in this light. The application of out-of-court solutions could be beneficial in this context. Also clean up and restoration standards should be assessed in the light of the costs they would be likely to generate. In order to be able to deal with historic pollution and other forms of pollution for which liability would not be a suitable instrument, for instance in case of diffuse damage, or in cases where the polluter cannot be identified, Member States could use - as some already do - other instruments, such as impact fees levied on polluting activities, or funds established at national or regional level.' (White Paper, $₫ 7 ., 29-30$ ).

Comparative law and economics, is also able to illustrate institutional priorities in the building of European Law. According to economic theory, institutional design should be aimed at lowering transaction costs (North, 1990), in order to favour the development of an efficient marketplace.

Since legal rules and institutions affect economic performance, the nature and functioning of European law making bodies becomes a central issue. With a view to evaluating the 
various forces at play in the formation of European private law, comparative law and economics can be employed in the analysis of the so-called "private legislatures", such as the Commission on European Contract Law (so called Lando Commission. See for a critical appraisal with insights from CLE: Hesselink, 2001) and the UNIDROIT. Scholars involved in the law and economics movement have studied the political economy of technical experts engaged in lawmaking in the United States (Schwartz and Scott, 1995). 'Their work suggests that these groups, no less than more conventional legislatures, confront the influence of interest groups and face systematic pressure to draft laws that fail to improve on the status quo and may produce overall welfare losses. Technocratic lawmaking, they argue, still has its own politics and is not necessarily improved by its freedom from broader political constraints (...). Summarizing the argument, the new work on the political economy of private lawmaking by bodies of technical experts predicts that: (1) many rules will vest considerable discretion in decision-makers, such as judges, rather than specifying outcomes that must flow from described circumstances; (2) those rules that are precise and constrain decision-makers will largely reflect the preferences of particular interest groups, such as banks, broadcasters, common carriers, etc.; and (3) the rules taken as a whole will not constitute a clear and definite departure from the status quo, because interest groups will enjoy considerable success in blocking any rules that encroach on their particular preferences' (Stephan, 1999).

Other useful insights can be drawn from the United States' institutional arrangements seen from the perspective of comparative efficiency. In the US, the products of any political choice (i.e. formal legal rules enacted by legislatures and executive power) are subject to a double mechanism of non-democratic professional control, effectively exercised by courts and legal scholars. In the traditional English common law, such role was played by courts alone, while in continental civil law systems the task used to be performed by academics alone. In the European Union today such professional controls are highly decentralized, complex, random and ineffective. The situation is made worse by a high deficit in democratic legitimacy in the formal rule making process of the political process. If the US institutional arrangement and interplay of professional and political-democratic legitimisation of sovereignty is to be seen as a success story (at least from the perspective of strengthening the domestic capitalistic model of development) from the comparative efficiency perspective priorities are clear. In Europe there is a need to strengthen the representative power of the Parliament and to create some sort of European judiciary (see, 
in the limited perspective of contract law, Mattei 1999). On the other hand, even the possibility to choose a novel different model of economic development finally confronting the major externality problems that western capitalism is still imposing on the post-colonial world, requires a major restructuring of institutional arrangement presently captured by global rent-seeking. Hence, the same priorities are recommended from both extremes of the political spectrum (See Gill and Law, 1993).

At present in Europe legal scholars have a scarce influence on the Brussels bureaucracy, as well as on the European Court of Justice. This lack of a common doctrinal background among the various European states, moreover, influences the process of national implementation of the formal legislation enacted by the European institutions. The whole purpose of integrating private laws of the fifteen European legal system may be frustrated by the absence of a common ground of legal discourse. Theoretical convergence may easily translate into operational divergence. Several barriers hinder communication. On the one hand, notwithstanding the enactment of common European rules, there are still radical differences in the conceptual backgrounds of national legal regimes, a legacy of past divergences. On the other hand, the meaning attributed to legal concepts and legal terms is too often the product of a complex debate conducted on a purely local basis and this fosters further divergences.

European private law, however, is a task that belongs to the European legal science, because open scholarly debates are less influenced by national and sectional interests and they can better serve as a procedural mechanism for efficient policy making. In the ongoing process of legal integration, therefore, the development of a strong pan-European legal scholarship should also be on top of the list of institutional priorities (see: Basedow, 2001).

\section{Globalisation and Americanisation: the critical value of comparative law and economics.}

The distinctive American flavour of traditional law and Economics leaves open a fundamental question that CLE attempts to tackle: what is the legitimacy of a scholarly paradigm when applied outside of the cultural context in which it has been developed and in which it has been able to gain influence? What are the political implications of using Law and Economics outside of the cultural environment in which it has developed? Is a new legitimacy necessary for the new context or is the one captured in its original environment 
sufficient also for the new one? In other words, is the diffusion of law and economics outside of the political context of the United States an episode of hegemonic diffusion of US law or are we in front of a new global legal order in which legitimacy gained in one place serves the purposes of the legal discourse everywhere?

These fundamental critical questions deserve a discussion if scholarship is not to be reduced to an ideological apparatus (in the sense discussed by Althusser, 1995) incapable of questioning fundamental patterns of power distribution (see Nader, 2001). Comparative law and economics urges approaching such fundamental critical questions within a broad historical context in which present trends are not taken for granted and in which local specificities are fully appreciated in their political meaning.

Such a critical exercise is even more needed if law and economics aims at establishing itself, as we have discussed in the previous sections, as one of the fundamental methodologies of the new European legal order (see Kennedy, 1998).

While much US scholarship has been devoted to broad issues and implications of using the economic approach to the study of the law, no such discussion has been carried on in Europe where Law and Economics has been marketed much more by means of institutional efforts (the European Association of Law and Economics has been founded years before its American counterpart!), than by actual processes of critical discussion about the epistemological conditions of the legal discourse.

Law and Economics has been able to gain its present day importance, significance and legitimacy in particular conditions that it is worth to briefly discuss. Today its messages and its approach are confronted in the US by a multitude of other scholarly paradigms, whose presence makes the discussion about the legitimacy of the legal order open to critique. In Europe, neither the history of Law and Economics nor the present day conditions of the scholarly debate can provide the critical check that is conceived as a precondition for lawyer's law to become legitimate in the Western Legal Tradition. We submit that comparative law and economics, as a discourse on legal institutions located at the boarder between interpretive and explanatory schools, might offer such critical appraisal of the hegemonic vocation of US law in the global legal landscape.

An unprecedented offspring of recent historical contributions on the value and limits of legal scholarship within the theory of US sources of law (Minda, 1999; Feldman, 2000; Mercuro \& Medema 1997) has pointed out that Law and Economics, born within a clear explanatory modern paradigm of legal scholarship, has entered a post-modern, interpretive 
phase of development in which its nature of a grand discourse over the essence of law aiming at objectivity has yielded to a local micro-strategy. Using such strategy, legal scholarship pursues hegemony and influence over the other sources of US law by means of a radically neo-pragmatist attitude (see Posner, 2001). Such critical development has been fostered by a general loss of faith in the objectivity of efficiency based discourses, the very same faith that in previous times have guaranteed to Law and Economics, and to economics in general, their hegemony within post-realist approaches to legal scholarship and within other social sciences respectively. (See Cooter, 1980). From the political perspective, to be sure, this is by no means the same than saying that Law and Economics in the US went through a transformation from an originally ontologically conservative political project to a post modern role of systemic critique shared with so many leftist paradigms of scholarly research such as for example legal feminism, critical legal studies or critical race theory. This only means that in the US Law and Economics has been forced to confront such alternative post-realist schools of thought and that, on the one hand, the contingent rather than ontological nature of its political creed has been exposed, while on the other hand the quasi-divine status of efficiency reasoning in the law (as more and more frequently used also by US courts and legislatures) has been radically questioned (see among many, Kelman, 1979). Such evolution can be seen in all its fundamental importance from the perspective of legitimacy of the legal discourse if only one takes into consideration that the quest for objectivity has been already at the roots of the legal process school in the fifties ( how to forget Wechshler's search for neutral principles in constitutional law), the first systematic scholarly attempt to a restoration of the legitimating strategies of legal professionals after the radical challenge of legal realism. In the United States, today, Law and Economics has been finally unseated from the throne of legal objectivity so that its normative recipes need a new contingent and local legitimisation in competition with those of a variety of opposite political strategies.

The exceptionally polarized or dialectical condition of academic debate over the law in the United States is notoriously absent from the European landscape. From the comparative perspective one can actually observe that such healthy adversarial debate between schools of thought is absent practically everywhere in the world, so that the image of a scholarly centre of the battlefield between opposite views (located in the US) and a huge periphery unaware of the political impact of scholarship as a source of law comes out dramatically reinforced (see on these notions of centre and periphery, Said, 1994). 
This situation should be regarded with worry particularly because the traditional grand theory of Law and Economics has been successfully received and implemented by the new almighty producers of global law, the international institutions of global governance, both private and public (the WTO, the World Bank, the IMF, the mega-law firms etc.). In this peculiar institutional scenario - successfully described by recent contributions as an "Empire" (Hardt \& Negri, 2000) or as a "Poliarchy" (Robinson 1996) -, even lively scholarly debates happening in one place only (however hegemonic such as the US) can not help to be parochial and ineffective, particularly as far as the voices of intellectual resistance and critique are concerned. The emerged false opposition between a global dimension, which is the domain of the market and of efficient institutions, and a local dimension, as the location of solidarity and politics, requires a genuine cosmopolitan legal culture to be exposed and challenged. In other words, what is currently required is a global jurist capable to handle analogies and differences, to locate them at the proper level of the institutional scenario, to register the different sensitivities and stakes that are at play in the centre and in the periphery; a global jurist capable, in one sentence, to deconstruct the objectivity of market globalisation worldwide. Such global jurist can neither be the traditional comparativist, nor the traditional US Law and Economics scholar.

As brilliantly pointed out in a recent essay (Reimann, 2001), traditional comparative law is particularly ill-equipped to tackle the critical analysis needed in order to study and understand the "new" legal systems of the global world, those non-territorial suppliers of law that characterise the present landscape (WTO, IMF etc.). Indeed, traditional comparative law is prisoner of a territorial national paradigm of inquiry (comparing e.g. Germany with US) that is all but dead as a tool for understanding legal globalisation. In order for the comparativist to become an effective global lawyer it is hence necessary to radically rethink her modernist idea of borders; the disciplinary ones with international law to begin with and, even more important, the territorial ones of the states, traditional subject matters of her inquiry. Tools must be invented to compare non territorial legal systems between themselves, as well as with territorial ones.

If the traditional comparativist is ill-equipped, the traditional Law and Economics scholars is at high risk of being transformed in an ideological weapon of hegemony. Its ideological bias in the process of modernization of the periphery carried on by the centre becomes entirely unacceptable when what is at stake is the creation of a new legal order governing the world's multitudes. Such new global legal order is as of today empty of the institutional 
accumulation of legitimising knowledge such as that provided by the dialectics of the scholarly debate within US law. It is hence void of institutions, both formal and informal, capable of grounding an authentic professional legitimisation - let alone of institutions capable of providing any sort of political legitimacy - to the new legal order.

The a-critical reception of Law and Economics with its grand discursive strategy based on efficiency and objectivity then becomes the ideological apparatus of global authority. Alternatively, when eventually (if at any point) the post-modern vein of US law and economics gets understood, the reception remains embedded in postmodernism "the logic by which global capital operates" (Hardt and Negri, 2000, at 151). In the United States, however, despite a number of contradictory characters, postmodernist legal paradigms have been able to "develop as a radical critique of both formalist and realist paradigms competing with each other for cultural hegemony in the legal academy... by challenging the American dream, the realist market paradigms and the simplifying assumptions of leading paradigms of research" (Mattei and di Robilant, 2001 at 1087). Even letting aside here the devastating impact of economic modernization carried on by means of western conceptions of the law in societies that have followed different paths of development, (see, for a classic critique, Gardner, 1980) it is clear that outside of the American cultural and institutional context legal phenomena are quite different, and such differences can not be easily repressed (see Mattei, 1998). For example, in the European legal landscape, still possessed as it is by the self serving formalist and localized attitude of the legal discourse, there is a need to introduce, perhaps for the first time, some values of modernity rather than to entertain postmodernist critique. A number of pre-modern aspects of European society (and of European notions of transcendent sovereignty) still strike the observer. For example formalism, a value symbolizing class division, has never been replaced by informality and openness not even as a grand rhetoric of legitimisation. Hence, in Europe postmodernism reinforces the pre-modern status quo even at a superficial level of analysis. In the complex and highly diversified rhizome of European law, the soft and pluralistic attitude of post-modern theory of the sources of law and legitimacy creates a legal paradise for the opportunistic forum shopping of predatory capital, outside of any public control (Nader, 2001). It moreover legitimises from a cultural perspective the forces opposing radical institutional remodelling of legislatures, courts and scholarship such as those discussed as priorities in the previous paragraph. 
These radical differences of social legal and economic context can be captured only by means of highly interdisciplinary tools of analysis capable of filtering the models produced in different legal contexts in order to make them viable in the new ones. Comparative law and economics can help in this daunting task that requires of course the contribution of many other scholarly tools within a genuine effort to make disciplinary frontiers crumble to be replaced by a more holistic social science.

There is, however, a more specific, humble and urgent task that comparative law and economics must approach immediately and that only it can perform. This is the task of organizing the resistance and the relentless critique of plain imports of US Law and Economics as a project of cultural hegemony. Such resistance can not take the form of a chauvinistic protection of localism in legal discourse or, worse, of an obscurantist scholarly practice refusing to take full cognition of the impressive body of legal and institutional knowledge produced by law and economics scholars in the U.S. (examples of such attitudes respectively in Legrand, 1999 and Zimmermann, 1994). Such resistance to be effective must take the almost paradoxical form of a filtered reception, of a selective process of discussion and adaptation of the models that appear as desirable in order to reverse the hegemonic trend by producing a potentially expansive alternative. In the European context, for example, such selection should be leaded by a painstaking effort to expose the values and preconceptions of Law and Economics that seem incompatible with the European model of capitalist development, a mixed private and public model in which certain aspects of communitarianism, solidarity and welfare are too strongly rooted and potentially foundational of an authentic international alternative to corporate globalisation to be simply disposed of as inefficient. Comparative law and economics has both the potentials to make such selection and those to pursue the best path available to cure the institutional corruptions and shortcomings that may reduces the chances of success of such alternative way. Of course, the comparative effort and the international shopping around for the best possible institutional possibilities has to be itself entirely cosmopolitan and not merely looking towards the other side of the Atlantic.

Chances are that, when the comparative legal and economic analysis is extended to the "efficient" institutions imposed by western dominated international organization to countries targeted by neo-colonial or imperial modernization projects, the critique is in need of being much more radical (see, in general: Kennedy, 1981). In such contexts a serious analysis of the local economic and institutional conditions is likely to suggest that 
resistance and counter-hegemony can only be provided by the process of political struggle. Even in such contexts, however, the instrumental and politically biased use of the efficiency thetoric - although poorly dissimulated to any unbiased observer - is still in need of being exposed, because it is an appealing tool of oppression for the local ruling elite (see for examples in Haiti, Chile, Costa Rica, Nicaragua and the Philippines: Robinson, 1996). 


\section{Bibliographical References}

Ajani, Gianmaria (2001), 'Legal Change and Economic Performance', Global Jurist Advances: Vol. 1: No. 1, Article 4.

http://www.bepress.com/gj/advances/vol1/iss1/art4

Ajani, Gianmaria and Mattei, Ugo (1995), 'Codifying Property Law in the Process of Transition: some Insights from Comparative Law and Economics', Hastings International and Comparative Law Review, 19, 117-137.

Althusser Louis (1995), Sur la réproduction, Collection Actuel Marx Confrontation, PUF, Paris

Antoniolli, Luisa (1996), La Struttura Istituzionale del Nuovo Diritto Commune Europeo: Competizione e Circolazione dei Modelli Giuridici (The Institutional Structure of the New European Common Law: Competition and Circulation of Legal Models), Università degli Studi di Trento: Dipartimento di Scienze Giurdiche.

Antoniolli, Luisa (1998), 'The European Institutional Structure, Legal Integration and the Europeanisation of Private Law', in F. Werro (ed.), L'Européanisation du droit privé - Vers un code civil européen?, Fribourg,CH: Editions universitaires Fribourg, 27-47.

Arthur, Brian (1994), Increasing Returns and Path Dependence in the Economy, Ann Arbour, Michigan University Press

Basedow Jurgen (2001), 'Codification of Private Law in the European Union; the making of a hybrid', European Review of Private Law, Vol. 9 No. 1, 35-49

Bussani, Mauro and Mattei, Ugo (1997), 'Making the Other Path Efficient: Economic Analysis and Tort Law in Less Developed Countries', in Buscaglia, Edgardo, Ratliff, William and Cooter, Robert (eds.), Law and Economics of Development, Greenwich, Conn.: JAI Press.

Bussani, Mauro and Mattei, Ugo (1998), 'The Common Core Approach to European Private Law', Columbia Journal of European Law, 3, 339-54.

Bussani, Mauro and Mattei, Ugo (eds.) (2000), Making European Private Law. Essays on the 'Common Core' project, Università degli Studi di Trento: Dipartimento di Scienze Giurdiche.

Bussani, Mauro, (2000) "Integrative" Comparative Law Enterprises and the Inner Stratification of Legal Systems', 8 European Review of Private Law 85 
Caruso, Daniela (1997), 'The Missing View of the Cathedral: The Private Law Paradigm of European Legal Integration," European Law Journal, $3,3$.

Cooter, Robert (1989), 'The Best Right Laws: Value Foundations of the Economic Analysis of Law', Notre Dame Law Review, 64, 817.

Cooter, Robert and Gordley, James (1991), 'Economic Analysis in Civil Law Countries: Past, Present, Future', International Review of Law and Economics, 11, 261.

Cooter, Robert, (1980), 'Law and the Imperialism of Economics: An Introduction to the Economic Analysis of law and a Review of Major Books', 29 UCLA L. Rev 1260

Cox, Robert W. (1987), Production, Power and World Order: Social Forces in The Making of History, New York, Columbia University Press

Dawson, John Philip (1968), The Oracles Of The Law, Ann Arbor, University of Michigan Law School

Feldman Stephen M. (2000), American Legal Thought From Premodernism To Postmodernism: An Intellectual Voyage, New York: Oxford University Press

Gambaro, Antonio (1983), 'Il successo del giutista', Il Foro Italiano, V, 85

Gambaro, Antonio (1998), 'Western Legal Tradition', in P. Newman (ed.), The New Palgrave Dictionary of Economics and the Law, Vol. 3, 686.

Gardner James A. (1980), Legal Imperialism. American Lawyers and Foreign Aid in Latin America, Madison, University of Wisconsin Press

Gill, Stephen and Law David (1993), 'Global Hegemony and the Structural Power of Capital', in Gill, Stephen (ed.), Gramsci, Historical Materialism and International Relations, Cambridge, Cambridge University Press, 93-124.

Grande, Elisabetta (2001), Imitazione e Diritto. Ipotesi sulla circolazione dei modelli, Turin: Giappichelli

Hansmann, Henry B. and Mattei, Ugo (1998), 'The Functions of Trust Law: A Comparative and Economic Analysis', New York University Law Review, 73, 434 479 .

Hardt Michael and Negri, Antonio, (2000), Empire, Cambridge: Harvard University Press 
Hesselink, Martijn W. (2001) 'The Principles Of European Contract Law: Some Choices Made By The Lando Commission', Global Jurist Frontiers: Vol. 1: No. 1, Article 4. http://www.bepress.com/gj/frontiers/vol1/iss1/art4

Katz, Avery (1996), 'Positivism and the Separation of Law and Economics', 94 Michigan Law Review 2229

Kelman, Mark (1979), 'Consumption theory, production theory, and ideology in the Coase Theorem', 52 Southern California Law Review 669

Kennedy, Duncan, (1981), 'Cost Reduction Theory as Legitimation', 90 Yale L. J. 1275

Kennedy, Duncan, (1998), 'Law and Economics from the Perspective of Critical Legal Studies', in P. Newman (ed.), The New Palgrave Dictionary of Economics and the $\underline{\text { Law }}$

Komesar, Neil (1994) Imperfect Alternatives. Choosing Institutions in Law, Economics and Public Policy, University of Chicago Press.

Kötz Hein (2000), 'Precontractual Duties of Disclosure: A Comparative and Economic Perspective', European Journal of Law and Economics, 9, 5-19.

Legrand Pierre (1999), Fragments on law-as-culture, Deventer W.E.J. Tjeenk Willink Mattei, Ugo (1994), 'Efficiency in Legal Transplants. An Essay in Comparative Law and Economics', International Review of Law and Economics, 14, 3-19.

Mattei, Ugo (1994a), 'Efficiency as Equity: Insights from Comparative Law and Economics', Hastings International \& Comparative Law Review, 18, 157-73.

Mattei, Ugo (1995), 'The Comparative Law and Economics of Penalty Clauses in Contracts', American Journal of Comparative Law, 43, 427-45.

Mattei, Ugo (1997), Comparative Law and Economics, Ann Arbor, MI: The University of Michigan Press.

Mattei, Ugo (1997a), 'Three Patterns of Law: Taxonomy and Change in the World's Legal Systems', American Journal of Comparative Law, 45, 5-44.

Mattei, Ugo (1998), 'Legal Change, Legal Pluralism and Economic Performance', in E. Grande, L.Favali, M. Guadagni (eds.), New Law for New States: Politica del Diritto in Eritrea, Turin: L' Harmattan Italia 
Mattei, Ugo (1999), 'Efficiency and Equal Protection in the New European Contract Law: Mandatory, Default and Enforcement Rules', Virginia Journal of International Law, 39,537

Mattei, Ugo (2001), 'Legal Systems in Distress: HIV-contaminated Blood, Path Dependency and Legal Change', Global Jurist Advances: Vol. 1: No. 2, Article 4. http://www.bepress.com/gj/advances/vol1/iss $2 /$ art4

Mattei, Ugo and Cafaggi, Fabrizio (1998), 'Comparative Law and Economics', in P. Newman (ed.), The New Palgrave Dictionary of Economics and the Law, Vol. 1, pp. 346-351.

Mattei, Ugo and Pulitini, Francesco (1991), 'A Competitive Model of Legal Rules', in A. Breton et al. (eds.), The Competitive State: Villa Colombella Papers on Competitive Politics, 207-219.

Mattei, Ugo, Antoniolli Luisa and Rossato Andrea (2000), 'Comparative Law and Economics', in Bouckaert, Boudewijn and De Geest, Gerrit (eds.), Encyclopedia of Law and Economics, Volume I. The History and Methodology of Law and Economics, Cheltenham: Edward Elgar, 0560, 505-538.

Mattei, Ugo, di Robilant, Anna, (2001), 'The Art and Science of Critical Scholarship: Postmodernism and International Style in the Legal Architecture of Europe', 75 Tulane L. Rev. 1053

Mercuro, Nicholas and Medema, Steven G. (1997), Economics and the law : from Posner to post-modernism, Princeton, N.J. : Princeton University Press

Minda Gary (1995), Postmodern legal movements law and jurisprudence at century's end, New York New: York University Press

Minda, Gary (1999), Boycott In America : How Imagination and Ideology Shape the Legal Mind, Carbondale, Ill. : Southern Illinois University Press

Monateri, Pier Giuseppe and Sacco, Rodolfo (1998), 'Legal Formants', in P. Newman (ed.), The New Palgrave Dictionary of Economics and the Law

Monti, Alberto (2001), 'Environmental Risk: a Comparative Law and Economics Approach to Liability and Insurance', European Review of Private Law, 1, 51-79

Nader, Laura (2001), Law in Motion. Anthropological Projects, Palo Alto: Stanford University Press 
North, Douglass (1990), Institutions, Institutional Change and Economic Performance, Cambridge University Press

Ogus, Anthony (1999), 'Competition between National Legal Systems: A Contribution of Economic Analysis to Comparative Law', International and Comparative Law Quarterly, 48, 405-418

Pierson, Paul (2000), 'Increasing Returns, Path Dependence, and the Study of Politics', American Political Science Review, 94, 251

Posner, Richard (1996), Law and Legal Theory in England and America, Oxford: Clarendon Press

Posner, Richard A. (2001), Frontiers of legal theory, Cambridge, Mass. : Harvard University Press

Reimann, Mathias, (2001), Beyond National Systems. A Comparative Law for the International Age', 75 Tulane L. Rev. 1103

Robinson, William (1996), Promoting Poliarchy. Globalization, U.S. Intervention, and Hegemony, Cambridge, Cambridge University Press

Sacco, Rodolfo (1991), 'Legal Formants: a Dynamic Approach to Comparative Law', American Journal of Comparative Law, 39, 1-34 (Part I); 343-401 (Part II).

Said, Edward W. (1994), Culture and Imperialism, Vintage Books

Schlesinger, Rudolf B. (1968), Formation of contracts; a study of the common core of legal systems, conducted under the auspices of the General principles of law project of the Cornell Law School, Dobbs Ferry, N.Y.: Oceana Publications

Schlesinger, Rudolf B., et al. (1998), Comparative Law: Cases, Text, Materials, 6th ed., New York: Foundation Press.

Schwartz, Alan and Scott, Robert E. (1995), 'The Political Economy of Private Legislatures', University of Pennsylvania Law Review, 143, 595

Stephan, Paul B. (1999), 'The Futility of Unification and Harmonization in International Commercial Law', Virginia Journal of International Law, 39, 743.

Van den Bergh, Roger (1994), 'The subsidiarity principle in European Community law: some insights from law and economics', Maastricht Journal of European and Comparative Law, 1:4, 337-366 
Watson, Alan (1974), Legal Transplants: An Approach to Comparative Law, Charlottesville, VA: University Press of Virginia

Watson, Alan (2000), 'Legal Transplants and European Private Law', Electronic Journal Of Comparative Law, vol 4.4, http://law.kub.nl/ejcl/44/44-2.html

Weiler, Joseph H.H. (1991), 'The Transformation of Europe', Yale Law Journal, 100, 2043

Zimmermann, R. (1994), 'Civil Code and Civil Law: The Europeanization of Private Law within the European Community and the re-emergence of a European Legal Science', 1 Columbia J. European Law 63

Zweigert, Konrad and Kötz Hein (1998), Introduction to Comparative Law, III revised edition, translated from the German by Tony Weir, Oxford: Clarendon Press. 